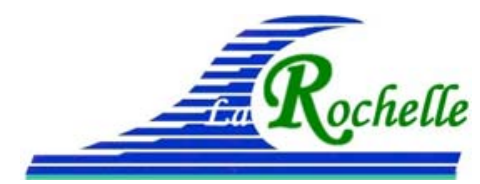

XVèmes Journées Nationales Génie Côtier - Génie Civil

La Rochelle, 29 au 31 mai 2018

DOI:10.5150/jngcgc.2018.050

(c) Editions Paralia CFL

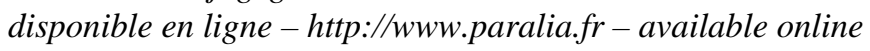

\title{
Cathodic protection challenges accelerated low water corrosion at Australian Ports
}

\section{Xavier HALLOPEAU ${ }^{1}$, Jack MCLEAN ${ }^{2}$, Nick CRITCHLEY ${ }^{2}$}

1. Freyssinet International \& Cie, Technical Department

280, avenue Napoléon Bonaparte, CS 60002, 92506 Rueil-Malmaison Cedex, France. xavier.hallopeau@freyssinet.com

2. Freyssinet Australia Pty Ltd

217 Arden Street, North Melbourne VIC 3051, Australia.

jmclean@freyssinet.com.au,ncritchley@freyssinet.com.au

\begin{abstract}
:
Accelerated Low Water Corrosion (ALWC), a form of microbiologically induced corrosion (MIC) that attacks submerged steel marine structures has become a major problem for ports, not only in Australia but also in western Europe. It is a well-known phenomenon and International codes cover the treatment, control and prevention of ALWC, even if prediction of corrosion rate and occurrence is difficult.

For ten years, many Australian Ports surveys detected the influx of ALWC causing bacteria in Port waters. If left untreated ALWC could cause a reduction in the service life of critical elements of Port assets.

To address the risk of ALWC, in 2015 the Port of Melbourne undertook a program for the design, installation and commissioning of impressed current cathodic protection systems to a number of wharf assets at risk of ALWC. This was undertaken with a focus on having the ICCP systems operational within 18 months. The systems were designed with tailored operational polarization criteria over and above that which is used to arrest more "typical" corrosion of steel in seawater.

This paper looks at the challenges of designing and installing these systems on operational wharf terminals, taking into account the conservative protection criterion of -900 $\mathrm{mV}$ instant $\mathrm{OFF}(\mathrm{Ag} / \mathrm{AgCl})$, the demanding working environment and the criticality of achieving protection in an accelerated timeframe.
\end{abstract}

Keywords:

Steel, Seawater, Accelerated low water corrosion, Cathodic protection, Criteria. 


\section{Thème 4 - Ouvrages portuaires, offshore et de plaisance}

\section{Introduction}

The Port of Melbourne is the largest container port in Australasia. With over 3000 ship visits annually, it is one of the most heavily utilized shipping facilities in the Southern Hemisphere. Over the last five years, routine diving inspections identified the presence of Accelerated Low Water Corrosion (ALWC) inducing bacteria on a number of Port of Melbourne assets in the Port Philip Bay and Yarra Entrance. As an identified risk to the structural capacity and ongoing use of steel wharf elements, a program was put in place to arrest this particularly aggressive form of corrosion.

To achieve this, a two-staged design, installation and commissioning program was undertaken for the delivery of Impressed Current Cathodic Protection (ICCP) systems on these critical wharf sites. In order to minimize the risk of disruption to the ongoing use of the Port facilities due to structural failure, this program of works was undertaken within an accelerated time frame, with a focus on delivering a tailored, turnkey solution for each unique site.

\section{Background}

Corrosion of steel structures in a marine environment is a commonly accepted risk that has been controlled and managed by asset holders for many decades via sacrificial steel thicknesses, protective surface treatments and cathodic protection. The predictability of common steel corrosion (or 'rusting') tends to allow programmed repairs and monitoring systems to control these risks within regular maintenance programs. According to the Maritime Navigation Commission however, within the past 20 years there has been a growing awareness of an accelerated form of corrosion localized at the low-water, tidal zone of maritime structures (Final Report of PIANC Working Group 44, 2005). This Accelerated Low Water Corrosion (ALWC), is a microbiologically induced corrosion (MIC) that results in rapid pitting of steel structures, linked with electrochemical reactions, much like differential aeration cells (KOPCZYNSKI, 2010). This highly aggressive type of corrosion is less predictable and its rapid onset can create significant challenges for an asset owner (KREHER et al., 2015).

After the advent of ALWC had been identified in surrounding waters along the SouthEast coastline of Australia, many port authorities introduced inspection programs to detect the orange bloom commonly associated with the corrosion. In 2014, the presence of ALWC inducing bacteria was detected at Port of Melbourne, in Victoria through routine diving operations. To address the risk of this bacteria and its potential effects on the structural capacity of these wharf assets; the asset owner, Port of Melbourne, decided to implement the use of Impressed Current Cathodic Protection (ICCP) systems on these assets. These works would be undertaken over a two-staged, 18-month delivery process.

To ensure successful delivery of this program of works, the four key success criterion for the Ports Delivery Strategy were: 


\section{XVèmes Journées Nationales Génie Côtier - Génie Civil \\ La Rochelle, 29 au 31 mai 2018}

- Deploy functional systems that address the ALWC whilst not in any way compromising normal operations of the terminals,

- Implement state-of-the-art intelligent systems so that remote control and monitoring is possible,

- Incorporate safety-in-design throughout the concept and detailed design process and,

- Develop installation methodologies that cater for uninterrupted terminal operations during the installation and commissioning process.

In order to achieve this program within the time frame, the works were staged in the following order:

i. Stage 1: 2 sites (30 and 33 South Wharf)

ii. Stage 2: 7 sites (Ann Street Pier, Gellibrand Pier, 32 South Wharf, 2 Webb Dock East, 3 Webb Dock East, Swanson Dock East Approach and Swanson Dock West Approach)

Design and installation works for these projects began in late 2015 with project completion mid-2017.

\section{Design concept}

The design of the impressed current cathodic protection systems was unique to each of the nine separate sites. Different layouts of tubular piles, raker piles and sheet pile walls called for each system to be tailored specifically for these differences as well as the practical implications of the sites ongoing use. Although each system was unique in its layout and arrangement, they were all based around the use of uniform materials and components that were adopted to allow for interchangeable spares and consistency of suppliers. For the ALWC works the following system components were used:

\subsection{MMO Titanium electrodes}

Mixed Metal Oxide coated Titanium (MMO Ti) tubular anodes were used as a distributed close anode system around each of the wharf structures. Two separate anode lengths were utilized being $1.0 \mathrm{~m}$ and $1.5 \mathrm{~m}$, depending on the required output voltage and depth of seabed. MMO Coated tubular anodes were ideal in this situation as MMO is specifically formulated to withstand the simultaneous effects of oxygen and chlorine which are likely to be found in Brackish/Sea Water in an environment like the Port of Melbourne (FUNAHASHI, 2013).

In order to ensure sufficient separation, current distribution and durability in the climate three different types of anode were used; jetty anodes (For piles), Bracketed Anodes (For Sheet Pile Wall) and Suspended Anodes (for both). See Figure 1 on next page.

\section{2 $\mathrm{Ag} / \mathrm{AgCl}$ Reference electrodes}

The design adopts the use of Silver/Silver Chloride/Sea water ( $\mathrm{Ag} / \mathrm{AgCl} / \mathrm{Sea}$ water) reference electrodes to monitor and check the performance of the cathodic protection 


\section{Thème 4 - Ouvrages portuaires, offshore et de plaisance}

system. These units are made of a thin silver wire electroplated with a thin layer of silver chloride. The reference electrodes used do not use a potassium chloride solution (as is often the case) but instead are stabilized by the natural chloride concertation of the surrounding water. This particular kind of electrode has been found in the authors experience to be more durable in an aggressive environment as they do not contain a porous membrane which can easily be damaged, resulting in unreliable measurements.

\section{3 $\underline{\text { Transformer rectifiers }}$}

The transformer rectifier units, see Figure 2 below, used a switch mode power supply for each individual anode being separately "zoned" for adjustable output control. Depending on the location, a number of separate Transformer Rectifier Units were often distributed evenly along the wharf each being "slave units" to a Central Control Unit (CCU) which included the remote monitoring and main control capabilities.

The benefit of using a TRU system like this is that each anode was individually controllable (ranging from 0 to 40 Amps of current) allowing for current to be distributed according to the protection requirements of each individual asset. This also allowed for smaller cable sizes to be used and less physical size requirements for the Transformer Rectifier Units themselves

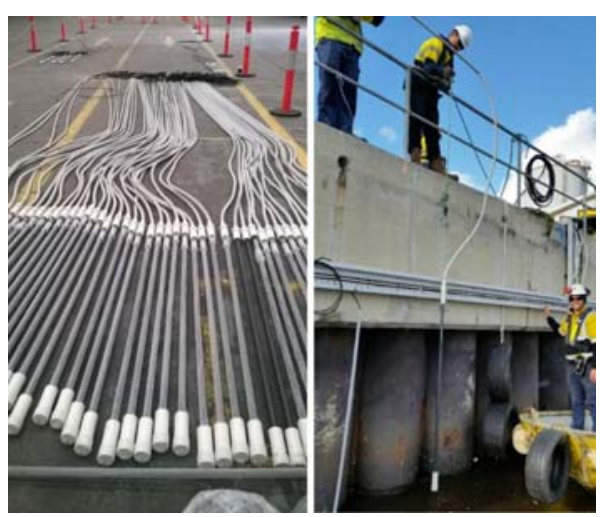

Figure 1. Tubular anodes.
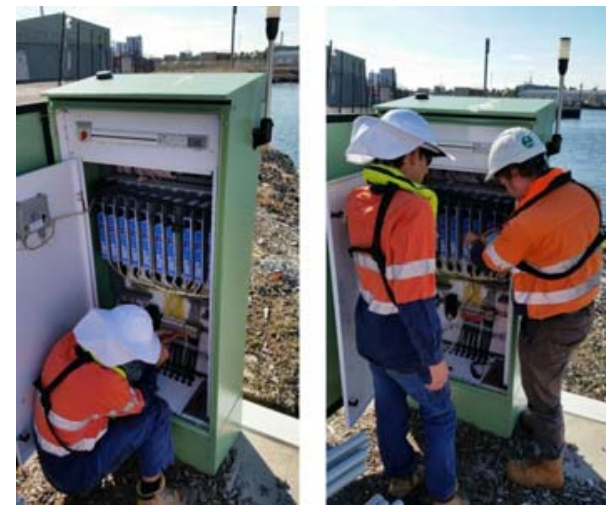

Figure 2. Transformer Rectifier Unit.

\section{Design considerations}

\subsection{Meeting $-900 \mathrm{mV}$ design criteria}

One of the principal challenges faced by a design team protecting steel under the effects of ALWC is the additional current requirement to halt corrosion. According to the report of working group 44 of the Maritime Navigation Commission, in aerobic conditions, protection of steel is achieved at an IR-free potential (ohmic drop free potential or Off potential) of $-800 \mathrm{mV}$ vs $\mathrm{Ag} / \mathrm{AgCl} / \mathrm{Sea}$ water reference electrode. This value is derived from Pourbaix diagrams and is quoted in many international standards 


\section{XVèmes Journées Nationales Génie Côtier - Génie Civil \\ La Rochelle, 29 au 31 mai 2018}

(EN 12495, 2000; EN 13174, 2012; AS 2832-3, 2005). In anaerobic conditions however, as is the case with ALWC, an electrical potential of $-900 \mathrm{mV}$ is required to suitably combat this aggressive form of corrosion.

From a design perspective, this $-100 \mathrm{mV}$ difference requires significantly more current. For the ALWC works, this was achieved by selecting some conservative design criteria, adopting an initial, average and final current density requirement $50 \%$ greater than that specified in AS 2832-3 (2005), as seen in table 1, below. Although this increase in current has significant implications for the system design and installation, the criticality of addressing this particularly virulent form of corrosion must be considered.

Table 1. Current density requirement - Aerobic vs anaerobic (ALWC) conditions journal.

\begin{tabular}{|c|c|c|}
\hline Current Requirement (AS 2832-3) & Bare Steel in Water & Bare Steel in Sea Mud \\
\hline Initial & $120 \mathrm{~mA} / \mathrm{m}^{2}$ & $20 m A / m^{2}$ \\
\hline Average & $90 \mathrm{~mA} / \mathrm{m}^{2}$ & $20 m A / m^{2}$ \\
\hline Final & $90 \mathrm{~mA} / \mathrm{m}^{2}$ & $20 m A / m^{2}$ \\
\hline $\begin{array}{l}\text { Adopted Current Requirement } \\
\text { (ALWC) }\end{array}$ & Bare Steel in Water & Bare Steel in Sea Mud \\
\hline Initial & $180 \mathrm{~mA} / \mathrm{m}^{2}$ & $30 m A / m^{2}$ \\
\hline Average & $135 \mathrm{~mA} / \mathrm{m}^{2}$ & $30 m A / m^{2}$ \\
\hline Final & $135 \mathrm{~mA} / \mathrm{m}^{2}$ & $30 m A / m^{2}$ \\
\hline
\end{tabular}

KREHER et al. (2015) pointed out that full mitigation of ALWC using sacrificial anode may not be achieved at $-900 \mathrm{mV}$ even the number of anodes would need to be increased from standard design to satisfy the initial and final current demand at a lower driving voltage of approximatively $150 \mathrm{mV}(-900 \mathrm{mV}$ less than $-1050 \mathrm{mV})$.

It becomes clear that provision of an impressed current cathodic protection (ICCP) system instead of a sacrificial anode system has considerable advantages to fight against ALWC: extra capacity to increase the current, designed for more than 30 years instead of 10-15 years for sacrificial anode systems.

\subsection{Design for longevity and climate}

In order to achieve a serviceable system life in a marine environment longevity of design must be considered. In a particularly aggressive marine climate, system componentry is exposed to tidal movements and splash zones which can seriously affect their usable service life. In order to ensure that the design for the ALWC program allowed for these conditions, appropriate material selection and installation techniques was integral. To achieve this the following requirements were specified as part of the design: 


\section{Thème 4 - Ouvrages portuaires, offshore et de plaisance}

- Outside of hazardous areas, a UV stabilised glass reinforced PVC cable tray was used. The advantage of adopting this material is the ease of workability and the resistance to corrosion.

- Inside hazardous areas, such as petrochemical wharf areas, cable tray was made from marine grade aluminum to allow for electrical continuity and earthing. The use of Steel Wire Armoured (SWA) cable was used. This provided additional mechanical protection and durability. It also must be noted that special, earthed hazardous area junction boxes were required where cables had to be joined. This added another element of complexity and required the use of specialist electrical personnel.

- Cable tray was hung from wharf soffits and mounted to the edge of capping beams where appropriate, care was taken to ensure that tray was installed as far from the splash zone as practicable. Additionally, locations for cable tray were selected where the risk of mechanical damage from day to day operations was also minimized. Both the PVC and aluminum cable tray can be seen in Figures 3 and 4 below.

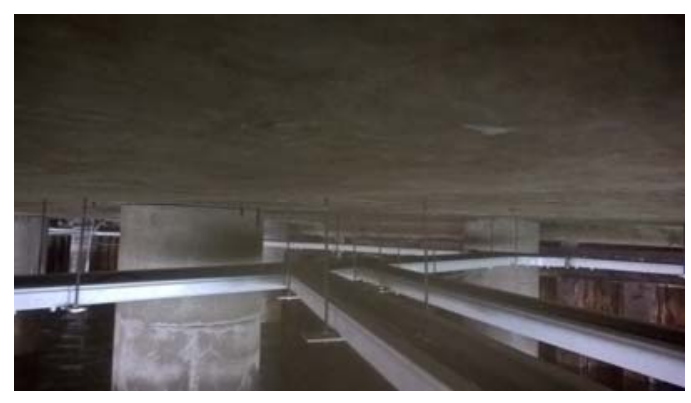

Figure 3. PVC cable tray.

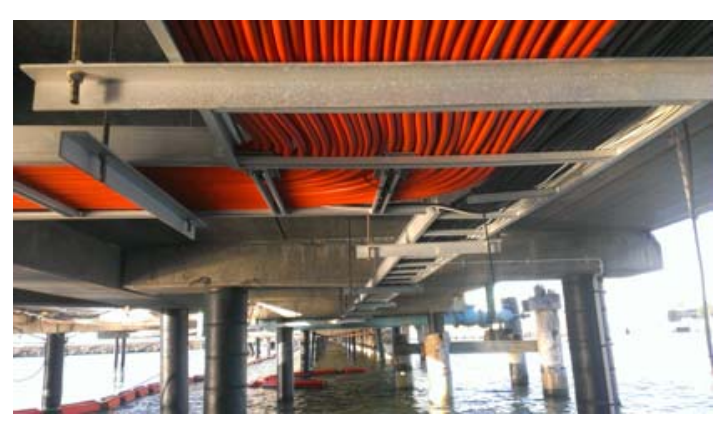

Figure 4. Aluminium cable tray.

\subsection{Sustainability for port operations}

Due to the rapid deterioration of steel under the influence of ALWC, regular monitoring and maintenance of the cathodic protection system must be undertaken to ensure its ongoing effectiveness. Although this is the case with any Cathodic Protection (CP) system, the deleterious effects caused by this particularly aggressive form of corrosion justifies a monitoring schedule above and beyond what may be required for a traditional cathodic protection system.

Planning for this monitoring and maintenance schedule across multiple sites presented a significant logistical design issue for the project team. In order to accomplish this, the Port of Melbourne specified that each individual Transformer Rectifier Unit be furnished with remote monitoring and adjustment capabilities. This afforded the benefit of real-time data systems checks, monitoring of protection levels and adjustments to system outputs as required. 


\section{XVèmes Journées Nationales Génie Côtier - Génie Civil \\ La Rochelle, 29 au 31 mai 2018}

Through system design, these online monitoring and adjustment capabilities allowed for safe and regular system checks at an increased frequency, whilst minimising the requirement to physically access isolated works areas.

\section{System commissioning and results}

System commissioning was undertaken according to the requirements of the Australian Standards (AS 2832-3, 2005) with absolute potential criteria being adopted as the more conservative Off potential vs $\mathrm{Ag} / \mathrm{AgCl} / \mathrm{Sea}$ water reference electrode (as detailed in section 4 above). Average Current across all sites was $\sim 11$ Amps per anode (just over $25 \%$ of the system capacity) with absolute protection criteria being achieved at all locations. This was monitored with an off test being undertaken at least once per day to check the polarization criteria and allow for output adjustments to be made as required. Protection was achieved within a 14-day period for each site with some areas polarizing within a number of hours after energization.

Once protection criteria had been achieved potential off tests were continued on a regular basis for a number of weeks following initial energization to ensure the structures were not being overprotected in some areas (potential off value greater than $1100 \mathrm{mV}$ vs $\mathrm{Ag} / \mathrm{AgCl} / \mathrm{Sea}$ water reference electrode).

It is interesting to note that although the system was considered "protected" at $-900 \mathrm{mV}$, it was anecdotally observed that the "orange bloom" that is resultant from the Microbiologically Induced Corrosion was still evident until it reached approximately $1000 \mathrm{mV}$ Off potential, where a calcareous deposit layer was evidenced, see Figures 5 and 6 below. Considering the amount of surplus current capacity of the system therefore it was decided that it would be adjusted to allow for an Off potential reading closer to $1000 \mathrm{mV}$ vs Ag/AgCl/Sea water reference electrode.

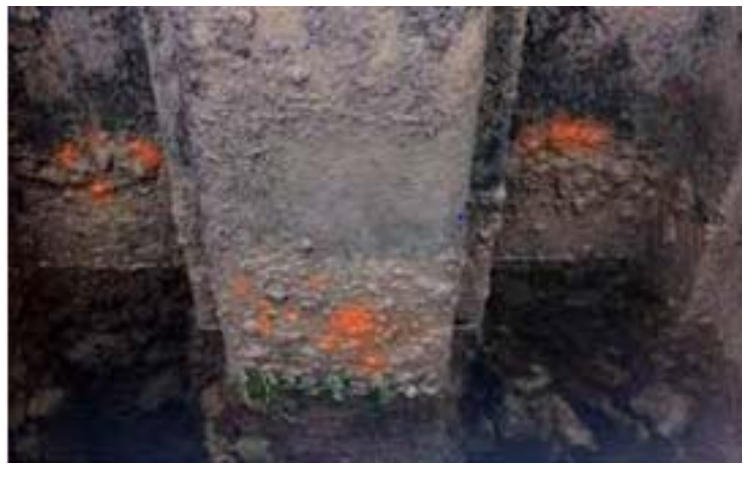

Figure 5. Orange bloom.

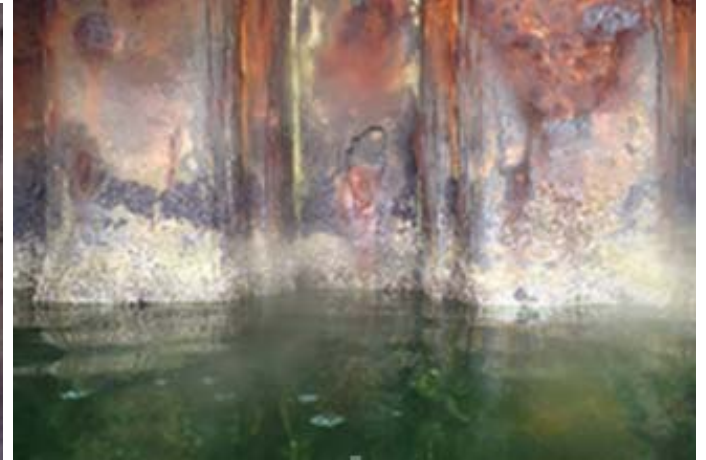

Figure 6. Calcareous deposit.

\section{Conclusions}

The use of ICCP systems for ALWC applications is a widely accepted practice that, when designed installed and commissioned correctly, can increase the usable life of a 


\section{Thème 4 - Ouvrages portuaires, offshore et de plaisance}

steel asset immensely. With the discovery of ALWC in the Port of Melbourne, the application of this type of system was deemed necessary to arrest this particularly aggressive type of corrosion.

In order to ensure continued success for future works, the following key findings and lessons learnt must be considered:

- Adoption of a conservative design criteria to allow for the additional current requirement to address ALWC. For the purpose of this program, a current density requirement $50 \%$ greater than a "typical" design was adopted.

- Design for durability and longevity of system materials and their componentry. Consideration has to be made for the fit-for use purpose of these materials over the systems intended design life.

- Innovative thinking and flexible use of access systems must be adopted to allow for variable conditions across multiple sites. Consideration must be made of environmental factors, productivity rates and health and safety of personnel.

- Sufficient lines of communication must be maintained at all times to ensure that key stakeholders are aware of all aspects of the works and that significant issues are identified and controlled as they arise.

- Programming and scheduling of works should be flexible and agile; ensuring that risk criticality can be addressed, early value can be delivered and economies of scale can be achieved.

Overall the delivery of this complex program of works was undertaken successfully with minimal disruptions to the Port of Melbourne and their tenants. Whilst considering the vast scope of works, design difficulties and the challenges involved for a safe and efficient installation; the project was able to achieve all four key criterion of the projects delivery strategy and was a major achievement to all of those involved.

\section{References}

AS 2832.3 (2005). Cathodic protection of metals - Fixed immersed structures.

EN 12495 (2000). Cathodic protection for fixed steel offshore structures.

EN 13174 (2012). Cathodic protection of harbour installations.

FUNAHASHI M. (2013) What you Need to Know about MMO Coated Metal Anodes. Nace Corrosion Conference 2013, Paper 2107, Orlando, USA.

KOPCZYNSKI B. (2010). Accelerated low-water corrosion in harbours. Port Technology International, Edition 46, 116 p.

KREHER U., VINNEL A., KHOSASI H. (2015). Mitigation of accelerated low water corrosion by cathodic protection - Background, challenges, examples. Corrosion \& Prevention 2015, Paper 126, Adelaide, Australia.

PIANC - International Navigation Association. (2005). Accelerated Low Water Corrosion (ALWC). Final Report of PIANC Working Group 44, PIANC General Secretariat, Brussels, Belgium. 